\title{
Çifte Maduniyet, Çifte işlev: \\ Ermeni Harfli Türkçe Basında Dil ve Kimlik
}

\author{
Murat Cankara \\ Ankara Sosyal Bilimler Üniversitesi Sosyal ve Beșeri Bilimler Fakültesi \\ murat.cankara@asbu.edu.tr
}

\section{Öz}

Osmanlı/Türk Tarih yazımı Ermeni basınını yalnızca Ermeni cemaati içindeki ișleviyle, sanki kapalı bir dünyaymıș gibi ele alma eğilimindedir. Bu tutum, Osmanlı milletlerinin birbirinden bağımsız kompartımanlarda yașayan topluluklar olduğu yönündeki tartıșmalı uzlașımdan olduğu kadar Ermenicenin diğer milletler için önemli bir engel teșkil etmesinden kaynaklanmaktadır. Okuyacağınız makalede bu tarihyazımı geleneğinin bazı iddialarının sorgulanması ve çürütülmesi amaçlanmaktadır. Bunu yaparken, ağılıklı olarak, Ermeni harflerini kullanarak Türkçe yayımlanan süreli yayınlara bașvurulacaktır. Öncelikle, 1915 yılına kadar yayımlanmıș olan Ermeni harfli Türkçe yayınlar ya da Ermenice yayınlarıdaki Ermeni harfli Türkçe metinler içerisinden ulașılabilir olanlar dikkate alınmıștır. Eldeki kaynaklardan art zamanlı (diachronic) bir seçim yapılmıș, bu yayınların bilhassa ilk sayılarında yer alan çıkıș yazıları ve sayfalarında yer verdikleri konu ve tartıșmalar incelenmiștir. Çalıșmanın bütünlüğü dil (Türkçe yazmak) ve kimlik (Osmanlılık-Ermenlik) temaları üzerinden sağlanmıș, varılan sonuç yer yer Ermenice ve Osmanlıca basına gönderme yaparak pekiștirilmeye çalıșılmıștır. Sonuç olarak bu yazıda, Ermeni basınının, bağlamına göre farklılık göstermeyen yekpare bir bütün olarak ele alınmasının ve indirgenmesinin sonuçları dile getirilerek eleștirilmiș, Türkçe yazmanın Osmanlı Ermenileri için anlamı üzerine kafa yorulmuș ve çift-kimlikliliğin (hem Ermeni hem Osmanlı) incelenen Ermeni harfli Türkçe yayınlarda nasıl savunulduğu gösterilmiștir.

Anahtar Kelimeler: Osmanlı/Türk tarihyazımı, Osmanlı basını, Ermeni harfli Türkçe, maduniyet, Türkçenin temellükü.

Makale geliș tarihi: 27.09.2015 • Makale kabul tarihi: 10.10.2015

http://ilefdergisi.org/2015/2/2/

ilef dergisi • (c) $2015 \cdot 2(2) \cdot$ sonbahar/outumn: 105-130 


\title{
Double-Subalternity, Double-Function:
}

\section{Language and Identity in the Armeno-Turkish Press}

\author{
Murat Cankara \\ Social Sciences University of Ankara Faculty of Social Sciences and Humanities \\ murat.cankara@asbu.edu.tr
}

\begin{abstract}
Ottoman/Turkish historiography has a tendency to give place to the Armenian press only with its communal function, as if it was totally isolated. The reason for this is not only the controversial argument that the Ottoman millets lived in compartments but also the fact that the Armenian language was more or less an insurmountable barrier to other millets. Here, by and large with reference to examples from the ArmenoTurkish press (that is, Turkish printed in the Armenian script), I aim to question and refute some of the claims of this historiography. I primarily focused on the Armeno-Turkish periodicals, or the Armeno-Turkish sections of the periodicals in Armenian, published until 1915, which were available to me. Having made a diachronic selection from the limited corpus at my disposal, I analyzed especially the first issues of these, as well as the discussions that took place across their pages. I achieved the integrity of the paper through the issues of language (the appropriation of Turkish) and identity (Armenianness-Ottomanness), and tried to support my findings by making occasional references to periodicals in Armenian and Ottoman Turkish. As a result, this paper pointed out the consequences of approaching Armenian press as a monolithic entity, reflected upon the meaning of writing in Turkish for Ottoman Armenians, and demonstrated how these periodicals advocated a double identity (both Armenian and Ottoman).
\end{abstract}

Keywords: Ottoman/Tukish historiography, Ottoman press, Turkish in the Armenian script, subalternity, the appropriation of Turkish. 
Bugün Osmanlı kültür tarihine dair bir akademik çalışmanın literatür değerlendirmesi kısmına genel olarak gayrimüslimlerin özel olarak da Ermenilerin söz konusu alandaki "katkılarının"1 görmezden gelinegeldiğini belirtmeden başlamak zordur. Ne yazık ki Osmanlı/Türk basın tarihi çalışmalarının da bundan münezzeh olduğunu söylemek kolay değildir. Bu tarihyazımında, tıpkı pek çok diğerinde olduğu gibi, Osmanlı basını deyince Osmanlı Müslüman/Türklerinin² Osmanlıca ${ }^{3}$ süreli yayınlarını kast etme eğilimi görülmektedir. Örneğin 70’li yılların meşhur ve yaygın kaynaklarından olan "100 Soruda" serisinin Hıfzı Topuz tarafından yazılan Türk Basın Tarihi cildinin yalnızca iki sorusuna sığdırılmıştır, Ermeni ve Rum basınları (Topuz 1973, s.85-91). Burada 19. yüzyıl Osmanlı basınının önemli bileşenleri olan Yahudi, Bulgar, Arap basını yer almadığı gibi, sahibi bir Rum, başyazarı Müs-

1 "Katkı" sözcüğünün son derece sorunlu olduğunu belirtmek gerekir. Osmanlı Ermenilerini Osmanlı'nın dışında görme tutumunun açık ifadelerinden biridir bu.

2 Bu denklemde Kürtler ve imparatorluğun diğer Müslüman tebası da yoktur.

3 Burada "Osmanlıca"yı Arap harfleriyle yazılan Türkçe anlamında kullanıyorum. Bu, gereksiz gibi görünmekle birlikte önemli bir ayrımdır zira Ermeni harfleriyle Türkçe metinlerin en azından bir bölümünün de aslında "Osmanlıca" yazıldıklarını söylemek gerekir. 
lüman ve müdürü Ermeni olan Sabah gazetesi de bu iki soru altında değil, diğer bir deyişle Türk basınına dahil edilerek ele alınmıştır. Burada kast edilenin "Türk"ten ziyade "Türkçe" basın olduğu düşünülebilir fakat bu durumda da Ermeni ve Rumların kendi alfabeleriyle yayımladıkları gazete ve dergilerin dışlanması durumu ortaya çıkar. Modern Türkiye tarihi açısından önemli bir dönüm noktası olan ve 1985 yılında İletişim Yayınları tarafından basılan 6 ciltlik Tanzimat'tan Cumhuriyet'e Türkiye Ansiklopedisi'nde de Osmanlı basınının çeşitliliğine yer verilmekle birlikte, temel tartışmalar Arap harfli yayınlar üzerinden gerçekleştirilmiştir. Ermeni harfli Türkçe süreli yayınlar üzerine ise bir inceleme yoktur. Osmanlı/ Türk basını tarihyazımının bir diğer önemli ismi olan Alpay Kabacalı Başlangıcından Günümüze Türkiye’de Matbaa, Basın ve Yayın başlıklı çalışmasında -ki bu da güncel bir yayındır- gayrimüslimlerin basındaki varlıklarını görmezden gelmez, ancak yine de "Azınlıkların Kurdukları Basımevleri" ve "Ermeni Matbaacıların Katkısı" türünden alt başlıklar kullanmaktan kurtaramaz kendisini. Üstelik burada da dönemin basını Osmanlıca süreli yayınlar üzerinden okunmaktadır (Kabacalı, 2000). Bu son iki çalışmadaki temel sorun gayrimüslim basınla Müslüman basınının etkileşim içinde değil, neredeyse birbirinden tamamen kopuk dünyalar olarak ele alınmasıdır. Daha da çarpıcı olan, günümüzdeki bazı yayınların bu anlamda yukarıda adı geçen çalışmaların çok daha gerisinde olabilmesidir. ${ }^{4}$

Şüphesiz, söz konusu tutum bütün bir basın tarihyazımına genellenemez. Dahası, bu türden bir dışlamanın önemli nedenlerinden biri kaynakların çok da görünür/ erişilebilir olmaması ve bunları okuyabilecek kişilerin azlığıdır. Dolayısıyla, Osmanlı/Türk tarihyazımının ilgi alanlarının son yıllardaki genişlemesi dikkate alındığında, Osmanlı/Türk basın tarihlerindeki bu tutumun da değişeceğini ön görmek pek yersiz olmaz. Bununla birlikte, özellikle Ermeniler söz konusu olduğunda Osmanlı'yı millet-i hâkimeye, diğer bir deyişle Müslüman/Türk kimliğine indirgemenin dikkat çekici bir boyutu daha bulunmaktadır ki bu basın tarihi açısından anlamlıdır. Temsil gücü yüksek, semptomatik bir örnek alalım:

Osmanlı ülkesinde üç ayrı nitelik taşıyan basınla karşılaşıyoruz: 1) Türkçe basın: Devletin bütünlüğünü savunmak zorunda olduğu için, Tanzimat'ın getirdiği Osmanlı milleti anlayışının ortaya çıkardığı İttihadı Anasır’ın savunuculuğunu

42014 yılında içinde sadece bir tane "Ermeni" kelimesi geçen -ki o da Takvim-i Vakayi'nin Ermenice de basıldığını belirtmek için kullanılmıştır- ve "Osmanlı' da Basının Doğuşu ve Gazeteler" başlığını taşıyan 32 sayfalık bir makale akademik bir dergide yayımlanmıştır ve ne yazarlar ne de hakemler burada bir metodolojik sorun görmüştür (Demir, 2014). 
yapmıştır. Türkçülük yapan bile bu çerçeveyi aşmamıştır. 2) Avrupa dilli basın (Fransızca, İngilizce, İtalyanca, Almanca): Kısa ve uzun vadeli ticari/mali oluşumları en ayrıntılı şekilde ele alan ve yönlendiren bunlar olmuştur. 3) Türkçe dışı yerel dilli basın: Kültürel canlandırmadan, ayrılıkçı ve ihtilalci eğilimlere kadar sosyal/ siyasal davranışların yönlendiricisi olmuşlardır. İstisnalar varsa da pek azdır (Koloğlu 2010, s. 28).

Orhan Koloğlu'nun bu tasnifinde iki temel sorun bulunmaktadır: 1) Devletin bütünlügünün savunulmasını Türkçe basınla özdeleştirmek suretiyle gayrimüslim basına "bölücülük" atfetmek; 2) Türkçeyi Müslüman/ Türklerle özdeşleştirerek gayrimüslimleri Türkçe basından dişlamak. Bu sınıflandırmayı Ermeni basını için yapılan şu değerlendirme takip eder: “Meşrutiyet'in ilanına kadar hemen tamamen İstanbul'da toplanmış olan Ermeni basını 1908'den sonra hızla Anadolu'ya yayılır. Çoğunluğu Orta ve Doğu Anadolu'da olmak üzere 46 gazete çıkmıştır. Artık bunlar eylemci ve ayrılıkçıdır. Amerikan misyonerleri ve Rusya'dan destek alıyorlardı" (Koloğlu 2010, s.46). Osmanlı/Türk basın tarihi konusundaki önde gelen isimlerden biri olan Koloğlu'nun yukarıda adı geçen güncel çalışmasındaki yaklaşım bir yana, genel olarak Osmanlı/Türk tarihyazımında Ermeni basınının nasıl temsil edildiğine bakıldığında daha da vahim bir tabloyla karşılaşılmaktadır. Bu tarihyazımı geleneğinde tamamılla Ermeni basınına odaklanan bir çalışma bulunmamakla birlikte, "Ermeni meselesi" üzerine kaynaklarda Ermeni basinından yekpare bir bütünmüş gibi söz etme ve onun "kışkırtıcı" ve "bölücü" rolünü -Koloğlu'nunkiyle karşılaştırıldığında çok daha sertçe- vurgulama eğilimi gözlemlenmektedir. İşin düşündürücü tarafı, bu kadar keskin yarg1ların yer aldığı literatürü yaratanların, bırakın Ermenice basını, Ermeni harfleriyle Türkçe basını bile birincil kaynaklara gönderme yaparak ele almamış olmasıdır. Diğer bir deyişle, genel eğilim tezi savunmak için kullanılan bilgiyi -dar sayıda örnekten yola çıkan ve kendisi de bir yerden aktaran- başka kaynaklardan aynen -yani doğruluğunu ve daha geniş örneklemler için geçerliliğini olduğu gibi kabul ederek- aktarmaktır. Yayımlayan kurum itibarıyla bu konuda temsil gücü oldukça yüksek bir kaynaktan, Genel Kurmay Başkanlığı'nın bastığı Ermeni Komitelerinin Amaçları ve Eylemleri (Meşrutiyet'in İlanından Önce ve Sonra) başlıklı kitaptan örnekler vermek yeterli olacaktır. Bu kaynakta bu yazının ileriki bölümlerinde adı tekrar geçecek olan Mgırdiç Khrimyan ve çıkardığı gazeteden şu şekilde söz edilmektedir: "Sonradan patrik ve katogikos olan Mıgırdiç Hrimyan 1857 yılında Van’da Varak Manastırı içinde bir basımevi kurdu. Ermeni bağımsızlığı amacını izlemek üzere 'Arziv Vaspuragan' (Van Kartalı) adındaki gazeteyi yayımlamaya başladı" (Tetik vd. 
2008, s.6-7). Kaynağa göre tüm bu “zararlı" fikirler yurda "dışarıdan” gelmiştir: "Rusya'daki Ermeni düşünürleri ve yazarları, daha eskiden beri gazetelerle, yayımladıkları kitap ve dergilerle Rus ve Osmanlı Ermenilerini, Türklere karşı kışkırtıyor"du (s.6); "Dışarıdaki Ermeniler, yurda ayaklanma yazıları göndermeye ve yayımladıkları gazeteleri sokmaya başladılar. Yurt içindekiler de zaten var olan hareketleri yönetmeye ve yaygınlaştırmaya çalışıyorlardı" (s.9). Kitap boyunca ister Ermenice olsun ister başka dilde, ister Osmanlı topraklarında basılsın isterse Avrupa ya da Rusya'da, Ermenilerin çıkardığı tüm süreli yayınlar "yıkıcı faaliyetler"le ilişkilendirilmiştir. Bu yayınlarla ilgili bilgiler de- en azından kaynak gösterilen örneklere bakılırsa- kapsamı bakımından Türkçe çalışmalar içerisinde hâlâ aşılamamış olup tek bir Ermenice süreli yayına doğrudan atıfta bulunmayan Esat Uras'ınkinden (halbuki Ermenice kitaplardan bol bol yararlanmıştır Uras) alınmıştır. Söz konusu “Ermeni meselesi" olduğunda Genel Kurmay'ınkiyle "sivil" ve akademik çalışmaların aynı noktada buluşabildikleri de görülmektedir. Örneğin, yine bir akademik dergide yayımlanan güncel bir yazıya göre, Mgrdiç Khrimyan 19. yüzyıl ortasında çıkarmaya başladığı gazeteyle Van'da bir "azınlık" olan Ermenileri sürekli isyana davet etmiş, isyan tohumları ekmiş; onun yolundan giden Ermeniler "bölücü" ve "zararlı" gazeteler çıkarıp "propaganda" yaparak "kötü emeller" ine ulaşmaya çalışmışlardır (Kardaş, 2013). Halkı isyana kışkırtmasalar bile dünyaya Osmanlı karşıtı görüşleri yayarlar: "Ermenilerin basın gücünün etkisi büyüktü. Osmanlı Devleti'ndeki her Ermeni hareketi daha 1890'l1 yıllardan itibaren Batı'da Ermenilere zulüm yapıldığı şeklinde yansıtılmıştır. Burada ortaya çıkan gerçek, propagandanın gücüdür. Avrupa kamuoyu herşeyden önce Ermenileri her konuda haklı görmekteydi" (Bakar 2009, s.137).

Bu makale 28-29 Mayıs 2015 tarihleri arasında Ankara Üniversitesi İletişim Fakültesi'inde gerçekleştirilen "Madunların Medyası: Tarihten Güncele Türkiye Anaakım Medyasının Dışında Kalanlar" başlıklı sempozyumda sunulmuş bir bildiriye dayanmaktadır. Bu çalışmada yukarıda örneklenen tutumun geçersizliği ve Osmanlı/Türk basın tarihinin çoğulcu bir perspektifle yeniden ele alınması gerektiği Ermeni harfli Türkçe süreli yayınlardan seçilen örnekler üzerinden savunulacaktır. Öte yandan şunu hemen belirtmek gerekir: Okumakta olduğunuz yazı, Ermeni harfli Türkçe basın tarihi üzerine kapsamlı bir incelemenin parçası değildir. Zira her ne kadar gün geçtikçe bu kaynaklara ulaşmak elektronik ortam vasıtasıyla kolaylaşıyorsa da Ermeni harfli Türkçe süreli yayın koleksiyonlarına ulaşmak ne yazık ki hâlâ çok kolay değildir. Dolayısıyla dil (Türkçe yazmak bağlamında) ve kimlik (OsmanlılıkErmenlik bağlamında) temaları üzerinden gidilecek, eldeki kaynaklardan art zamanlı (diachronic) bir seçim yapılacak ve zaman zaman Ermenice basına da 
gönderme yaparak hem bir sağlama hem de bir bütünlük elde etmeye çalış1lacaktır. Burada kapsamlı bir değerlendirme ya da bir dergi üzerine ayrıntılı bir inceleme yapmak değil, yaygın bir yaklaşımı mevcut kaynaklar ve Ermeni harfli Türkçe yayınlar bakımından süreklilik arz eden iki tema üzerinden eleştirerek daha geniş kapsamlı çalışmalar için bir çıkış noktası sunmak amaçlanmaktadir.

\section{Soru(n)lar}

Yukarıda da belirtildiği üzere, bu makale akademik bir sempozyumda seçilen tema çerçevesinde sunulduğundan, söz konusu temayla ilişkisine değinmek yararlı olacaktır. Şu soruyla başlanabilir: "Madun" ve "medya" kavramları birlikte kullanılabilir mi; madunun medyası olur mu? "Madunun medyası" bir oxymoron mudur? Madunun kim olduğu, hukukî azınlıkların ya da ötekileştirilmiş, baskı gören tüm toplumsal grupların madun sayılıp sayılamayacağı ise ayrı bir sorundur. "Madun" - "medya" ilişkisi başlı başına teorik bir tartışmayı gerektirmektedir ve bu tartışma okumakta olduğunuz makalenin içeriğine doğrudan katkı sağlamayacaktır. Bununla birlikte, "madun" - "medya" ilişkisi üzerine bir tartışmanın Osmanlı basın tarihinde Ermenilerin konumunu ilgilendiren bir yanı bulunmaktadır. Zira madunun medyası olabileceğini kabul etsek bile şu sorudan kaçmak zordur: Ermeniler madun mudur? Eğer madunluğu kendi kendini ifade etme kapasitesinden ve araçlarından yoksunluk olarak tanımlarsak, Ermenilere madunluk atfetmek haksızlıktan öte büyük bir çarpıtma olacaktır. Burada genel olarak Ermeni yazılı kültüründen özel olarak da Ermeni matbaacılık tarihinden uzun uzadıya söz etmeye gerek bulunmamakla birlikte, Ermenilerin bilhassa alfabelerinin yaratıldığ1 5. yüzyıldan beri zengin bir yazılı kültüre sahip olduğunu, Ermeni tarihlerinde Altın Çă̆ olarak adlandırılagelen dönemde özellikle Yunanca ve Süryaniceden pek çok eserin Ermeniceye tercüme edildiğini, ilk matbaalarını Venedik'te kurup 1512 yılında bu matbaada kitap bastıklarını ve 19. yüzyıl boyunca Osmanlı topraklarındaki yayıncılık faaliyetlerini -burada 1855'te Van'da gazete basmaktan bahsediyoruz- hatırlamak, Ermenilerin bu anlamda madun olmadıklarını göstermeye yeter. Üstelik yüzlerce yıllık matbaa gelenekleri sayesinde dökümcü, dizgici vb. olarak Osmanlı basınında oynadıkları öncü rolleri hesaba katıldığında durum daha da netleşmektedir: ${ }^{5}$ Kısacası, geç Osmanlı hatta erken Cumhuriyet matbaa kültürünü Ermenileri içinden çıkararak anla(t)mak mümkün değildir. Şu örnek yeterince çarpıcıdır: 1928'de Latin harflerinin kabulünden sonra Mustafa Kemal'e hediye edilen altın alfa-

5 Bu konuda daha fazla bilgi için, bkz. (Teotig, 2012) ve (Yarman, 2012). 
be levhasının "ihalesini cevahirci Hrant Babayan alır. Tasarımını S. Agayan'ın yaptığı tasarımın imalatını ise kuyumcu Levon Mazlumyan üstlenir" (Oral 2010, s.34).

Bu durumda şunu söylemek yerinde olacaktır: Ana akım Osmanlı/Türk tarihlerinin Ermenileri bir şekilde dışarıda bırakması Ermenilerin dilsizleştirilmiş, yani madun oldukları anlamına gelmez; bilakis, söz konusu tarihyazımının zayıflığını ve yeniden düşünülmesi gerektiğini gösterir. Öte yandan, Ermenilerin önemli bir bölümünün millet-i hâkimenin dilini kullanarak Türkçe konuşması ve yazması bu meseleyi biraz karmaşıklaştırmaktadır. Ermenilerin Türkçeyi sahiplenmeleri (appropriation) henüz sosyolinguistik açıdan incelenmiş bir konu olmamakla birlikte, durumu açıklamaya çalışan bazı çabalar mevcuttur. Meşhur Ermeni dilbilimci Hraçya Acaryan'a göre -ki bu konuda bir otorite sayılabilir- Ermenilerin Türkçeyi benimsemelerinin nedeni, yaklaşık bin yıl boyunca çeşitli Türk kavimlerinin hakimiyetinde yaşamalarıdır. Bu dili 13. yüzyılda öğrenmeye başlayan Ermeniler, Osmanlı yönetiminin zaman zaman despotik uygulamalarının sonucu olarak imparatorluğun belli bölgelerinde Ermeniceyi tamamen unutup Türkçe konuşmaya başlamışlardır. Ayrılıkçı Katoliklerin Ermeniliğe dair her şeyden tiksinerek Ermenice yerine Türkçeyi tercih etmeleri de bu dilin Ermeniler arasındaki yaygınlığının nedenleri arasındadır (1902, s.5; 1951, s.255-267). Acaryan'ın Ermenilerin Türkçeyle ilişkisine dair çalışmaları burada ele alınamayacak kadar ayrıntılıdır. Ancak her halükârda kendisinden sonraki kuşakların çalışmaları doğrultusunda gözden geçirilmesi gerektiği de aşikârdır. Tutarsızlıkları bir yana, bazı iddialarının bugün artık açıklanması gerekir. Örneğin, Ermenilerin kendilerine "yabancı ve barbar" bir dili doğrudan bir baskının olmadığı bölgelerde nasıl ve niçin benimsediklerini açıklayamamışır, Acaryan. Dahası, kaynak kullanmadan geçiştirdiği bazı noktaların üzerine gidilmesi gerekir. Örneğin, dil söz konusu olduğunda Türk yöneticiler Ermeniler üzerinde ne zaman, nerede ve nasıl bir baskı mekanizması kurmuşlardır? Öte yandan, Ermenilerin bir kısmının anadil olarak Türkçeyi konuşmaları gerçeğinin bir alt kümesi olarak Ermeni harflerini kullanarak Türkçe yazmaları meselesine ${ }^{6}$ baktı̆̆ımızda, Ermenice değil de Türkçe yazmak, Ermeni harflerini kullanarak Türkçe

6 Burada "mesele" teriminin tercih edilme nedeni, henüz bu konuda yeterli sayıda ve tatmin edici düzeyde çalışmanın bulunmamasıdır. Bu konuda Türkçe daha fazla bilgi için, bkz. (Kut, 1985), (Kraelitz-Greifenhorst, 1996), (Koptaş, 2002), (Stepanyan, 2005), (Cankara, 2011) ve (Cankara, 2014). Farklı alanlardan metin örnekleri için bkz. (Pamukciyan, 2002), (Altounian vd. 2014) ve (Koz, 2014). Batı dillerinde değerlendirmeler için bkz. (Hetzer, 1987) ve (Cankara, 2015). 
yazmak ya da yazarken -kendi deyişleriyle- "kaba Türkçe" kullanmak -ki burada söz konusu olan gündelik konuşma dilidir- sosyolinguistik açıdan düşük prestijli durumlardır. ${ }^{7}$ Burada hem kullanılan dil hem o dilin kullanılan varyant ${ }^{8}$ hem de nereden baktığınıza bağlı olarak seçtiğiniz dil-alfabe kombinasyonu açısından bir "aşağı olma" durumu söz konusudur. Dolayısıyla Ermeni harfli Türkçe yayınlar için belki tam olarak kavramın sömürgecilik sonrası çalışmalarındaki anlamıyla değil ama sözcüğün asıl anlamıyla, yani Arapçadaki " $m a$ " ve "dîn" sözcüklerinin bir araya gelmesiyle ortaya çıan "aşağıda olan" anlamında bir maduniyetten bahsedilebilir; hem de çifte bir maduniyet. Ermeni harfli Türkçe yazmayı seçen bir yazar hem Türkçe yazdığı hem bu dili yazarken Ermeni harflerini kullandığı hem de bu dilin yazı görmeye pek alışık olmayan aşağı varyantını kullandığı için aşağıdadır, ötekidir. ${ }^{9}$

Soru(n)lar burada bitmiyor: "Ermeni basını" deyince ne anliyoruz? Ermenilerin Ermenice çıkardığı süreli yayınları mı? Ermeni harfleriyle Türkçe basin bunun neresinde duruyor? Protestan misyonerlerin Ermenice yahut Ermeni harfleriyle Türkçe çıkardığı yayınları ne yapacağı?? Bu yayınların yönetici ya da yazar kadrosu sadece Ermenilerden oluşmuyor. Ya da Mihran Nakkaşyan'ın (1850-1944) Sabah gazetesi örneğinde olduğu gibi Ermenilerin Arap harfleriyle çıkardıkları gazete ve dergiler ne olacak? Hepsinden de öte 19. yüzyıl Osmanlı Ermeni cemaatinden söz ederken İstanbul-taşra, Apostolik-Katolik vb. iç bölünmeleri hesaba katmayan yaklaşımlar, daha en baştan bir tür "safsata"10 (örneğin, association fallacy) yapmaya mahkumdur. Fakat tüm bunlara rağmen, bir Ermeni basını -hem de güçlü ve zengin bir basınvardır, bu yayınların azımsanmayacak bir bölümü de Ermeni harflerini kullanarak Türkçe basılmıştır ve zaman ve mekâna bağlı olarak biçimi ve şiddeti değişmekle birlikte Ermenilerin çeşitli baskılara maruz kaldıkları da açıktır. O halde niçin bu konuda bir makale yazılmasın?

7 Sosyolinguistikteki "prestij” kavramına dair bir çerçeve için bkz. (Sairio vd. 2012).

8 Burada, genellikle resmî eğitim yoluyla edinilen ve bir yazı dili olan yüksek varyanta (high variety, $H$ ) karşılık, gündelik iletişim için kullanılan alçak varyanttan söz ediyorum (low variety, $L$ ). Osmanlı Türkçesi bağlamında yüksek varyant,Arapça ve Farsça kelimelerle tamlamaların daha yoğun kullanıldığı ve genellikle "Osmanlıca" olarak adlandırılan belâgatli yazı dilidir. Alçak ve yüksek varyantlar üzerine temel bilgi ve örnekler için bkz. (Wardhaugh 2006, s.85-92).

9 Ermeni harfli Türkçe edebiyat ve minör edebiyat tartışması için bkz. (Cankara 2011, s. 394408).

10 Burada sözcüğü İngilizcedeki "fallacy" sözcüğünün karşılığı olarak, yani teknik anlamda kullaniyorum. 


\section{Ermeni harfli Türkçe basında "Türkçe yazmak" meselesi}

Ermeni harfli Türkçe basında "Türkçe yazmak" meselesini ele almadan önce Ermeni basınının ve bu konudaki kaynakların çok genel bir çerçevesini çizmekte yarar vardır. Bu konuda Türkçe ${ }^{11}$ üç kaynaktan söz edilebilir. Bunlardan sadece bir tanesi doğrudan basın hakkındadır:

Zakarya Mildanoğlu'nun Ermenice Süreli Yayınlar: 1794-2000 (2014) başlıklı çalışması. Mildanoğlu 1794-2000 arasında toplam 3647 adet Ermenice süreli yayının künyesini vermektedir. Buna göre ilk Ermenice süreli yayın 1794'te Madras'ta (Hindistan) yayımlanan Aztarar'dır [Haberci]. Hasmik A Stepanyan'ın Ermeni Harfli Türkçe Kitaplar ve Süreli Yayınlar Bibliyografyası: 1727-1968 (2005) başlıklı çalışmasında ise 1840-1947 arasında basılmış toplam 119 (18'i el yazması) Ermeni harfli Türkçe süreli yayının künyesine yer verilmiştir. Bunlardan ilki İstanbul'da yayımlanan Takvim-i Vakayi; sonuncusu da İskenderiye'de el yazması olarak çıkan Avedarani Tsayn'dır [İncil'in Sesi]. Mildanoğlu ise kitabının sonunda 72 adet Ermeni harfli Türkçe süreli yayının künyesini vermektedir. Bunların içinde Khelas [Kurtuluş] Fresno'da 1950'ye kadar yayımlanmıştır. Son olarak da Teotig' in $^{12}$ (1873-1928) Ermeni harflerinin icadının 1500. ve Ermeni matbaacılığının 400. yıldönümü olan 1912 yılında basılan Baskı ve Harf: Ermeni Matbaacıllk Tarihi başlıklı çalışmasına değinmek gerekir. Bu daha ziyade Ermeni matbaacıllğı hakkında bir çalışma olmakla birlikte, basına dair de önemli bilgiler içermektedir. ${ }^{13}$

O halde şimdi -yukarıdaki bütün çekinceler saklı olmak koşuluyla- Ermeni harfli Türkçe basında "Türkçe yazmak" eyleminin nasıl değerlendirildiği sorusuna yanıt aranmaya başlanabilir. Aşağıdaki satırlar 19. yüzyılın ikinci yarısında Osmanlı Ermenilerinin en önde gelen toplumsal figürlerinden biri olan Mgirdiç Khrimyan'ın ${ }^{14}$ (1820-1907) önce İstanbul'da sonra Van'da çıkar-

11 Ermenice kaynaklar için bkz. (Zarbhanalian, 1905) ve (Paployan, 1986).

12 Asıl adı Teotoros Lapçinciyan'dır.

13 Bunlar haricinde (Pamukciyan, 2002), (Pamukciyan, 2003) ve (Tuğlac1, 2004) de Ermeni basını hakkında önemli bilgiler içermektedir. Tuğlacı'nın bu konuda Tarih ve Toplum dergisinde yayımlanmış yazıları da bulunmaktadır ancak kapsam bakımından en önemli çalışması 5 cilt halinde çıkan Batı Ermenileri Tarihi' dir.

14 Khrimyan hakkında daha fazla bilgi için bkz. (Bardakjian 2013, s. 148-9, 466-68). 
dığı ve bölgedeki ilk süreli yayın olma özelliği taşıyan Ardzvi Vasburagan'da ${ }^{15}$ (Van Kartalı) yayımlanmış bir mektupta ${ }^{16}$ yer almaktadır:

Evvela mektubum bütün müddet-1 ömrümde kalbimi memnun [?] iden bir mahzuniyetin sebebini ifade idecek ve şübhem yok ki, sizler dakhi ol mahzuniyetimin aslına agâh oldığınızda, teessüfümden müteessif olacaksınız; zira ben-i ademe kendi vetanının lisanını okumak, yazmak, ve söylemek böyük bir borç ise, ben o borcun edası esnasında, hayıflar olsun niçe niçe sebeblere mebni, tedariksiz bulunmuşım dır; vaktım geçmiş, yanğın bacayı sardıkdan songra aklıma geliyor ki, bu ateşi sakınmak içün, elde su hazır yanında beklemeli imiş. Aklım başıma geldiği esnade, bendenizin dakhi, sehvimi doğrutmaya takat kalmamış ıdı; zira (ağac yaş iken doğrulur), işte mahzuniyetim, işte hayrenikimin lisanından [vatanımın lisanında, yani ana dilimde] yazamadığım içün kalbime zuhur iden teellüm. Lakin acaba, bu kusur yalınız benim mi? Hayır; milletimizden yüzde seksenin ki, vetan kitabetine aşna olmadıklarından sarf-1 nazar, elfazlar hakk1na bile, millet-1 aher lisanına mühtac olmuşlar dır; işde Fazilatlü Pederim, işde benim teessüfümin aslı. Reca iderim, bu mektubu türkce gördügünüzde taacüb itmeyiniz, zira elden gelen bu kadar dır (“Namag” 1858, s.266-267). ${ }^{17}$

Yukarıdaki satırlarla açılan bu mektup derginin editörü Khrimyan'a hitaben yazılmıştır ve dergi sayfasıyla beş sayfadan uzun tutmaktadır. Hemen başında Khrimyan'ın yaklaşık iki sayfalık bir yazısı bulunmaktadır ve anlaşıldığı kadarıyla bir yandan Türkçe bilmeyenler için yazıyı özetlemek, diğer yandan da mektubun sahibine teşekkür etmek için yazılmıştır. Mektubun yazarı Khrimyan'ın yıllık bağış kampanyasına katkıda bulunmak için yazmıştır ve 1856 senesi için yapmış olduğu gibi bundan sonra her sene Khrimyan'ın açmış olduğu ruhban okulu, kurduğu matbaa ve çıkardığı dergi için kullanılmak

15 Önce İstanbul'da daha sonra Van'da yayımlanan dönemin önde gelen aydınlarının katkıda bulunduğu bu aylık süreli yayın hakkında Mildanoğlu şu bilgiyi veriyor: "Anadolu Ermeni coğrafyasının karanlık ve kanlı yüzüne, Ermenilere yönelik kırımlara yer verir. Gençliğe, umutsuzluğa kapılmadan örgütlenme çağrısında bulunur. Hükümetin uygulamalarını protesto eder. 1860'da özgürlük mücadelesi kavramı çerçevesinde bir dizi makale yayımlar. Ermeni Anayasası'nın taşrada uygulanması üzerine yayın yapar. Dini ve ahlaki konulara geniş yer ayırır. Rusya Ermenileri ile ilgili bir dizi makale yayımlayarak Doğu-Batı Ermeni ilişkilerinin güçlendirilmesini amaçlar. Ermeni köylerindeki eğitim ve öğretmen sorunlarına yer verir" (Mildanoğlu 2014, s.31).

16 Mektuba dikkatimi çeken meslektaşım Dzovinar Derderian'a teşekkür ederim.

17 Ermeni harfli Türkçe alıntıları Latin harflerine aktarırken Batı Ermenicesindeki telaffuzu esas aldım. Onun dışında yazımı ve noktalamayı mümkün olduğu kadar, hataları ve standart dışı uygulamaları da koruyarak, aslına sadık bir biçimde bırakmaya çalıştım. Köşeli parantez içindeki ifadeler bana aittir. 
üzere 500 kuruş göndereceğini belirtmektedir. Mektubun kalanı Khrimyan'ın cehalete karşı açtı̆̆ı savaş ve Ermenistan'ın eğitim yoluyla aydınlanması ve ilerlemesi için verdiği mücadeleye övgüden ibarettir. Burada dikkat çekici olan, yazarın Hayrenik (vatan) sözcüğünü sık sık kullanması, hatta Ermenice için "Hayrenikimin lisanı" ifadesini kullanmasıdır. Ardzvi Vasburagan'ın ve genel olarak da Khrimyan'ın çalışmalarının Osmanlı Ermenilerinde bir millî bilincin uyanması ve vatan tahayyülünün şekillenmesi sürecinde ne kadar önemli rol oynadığı düşünülürse, ${ }^{18}$ yukarıda alıntılanan mektubun, Ermenice yerine Türkçe kullanıyor olmaktan dolayı bir özürle başlaması ayrı bir önem kazanır. Basının gelişmesi ve süreli yayın sayısının hızla artmasının Ermeni harfli Türkçe yazma pratiği açısından anlamı dikkate alındığında durum daha iyi anlaşılabilir: Bir yandan Ermeni harfli Türkçe basın açısından çok pratik bir tercihtir, zira hem kullanılan dilin basitliği hem alfabenin bu dile uygunluğu hem de muhtemel hedef kitlenin önemli bir bölümünün ya ana dilinin Türkçe olması ya da en azından Türkçeyi anlayabilmesi nedeniyle çok daha geniş bir kitleye (hatta Ermeni olmayanlara) ${ }^{19}$ ulaşılmasını mümkün kılmaktadır. Diğer yandan basının kendisinin de gelişmesinde öncü rol oynadı̆̆ı millî bilinç açısından kabul edilmesi çok güçtür, çünkü milliyetçi tahayyül için bir milletin tek ve ancak tek bir dili olabilir; ${ }^{20}$ üstelik o dilin kadim olması, milletin tarihiyle iç içe geçmesi gerekir. Dolayısıyla Ermeni harfli Türkçe basında özür ve meşrulaştırma neredeyse başından sonuna kadar el ele gider. Benzer bir durumu İkinci Meşrutiyet sonrasında çıkan Hüsn-i Niyet'te ${ }^{21}$ de gözlemlemek mümkündür. 1911 yılında, yukarıdaki mektuptan yarım asır sonra, İstanbul' da ve sadece tek bir sayı yayımlanan bu aylık dergide editöre hitaben yazılan bir mektuptan alınan şu satırlar, Ermeni harfleriyle Türkçe yazmanın niçin gerekli olduğunu açıklamak için yazılmıştır:

"Hüsn-i Niyet" in mebdesi, kendi kariyn-i kiramını cihanın terakkıyatından haberdar idub, alem-i medeniyetin muşaşa ufukına doğru götürmek, ve vaktında mekteblerimizin nizamsızlığı sebebi ile ülum $u$ finun ve elsine-i ecnebiyeden bibehre kalan, efkârın tenvirine hızmet itmek olması ehemm ve elzem dir. Milletdaşlarımız meyanında, lisan-ı maderzadını bilmeyub, yalınız türkce tekellüm iden-

18 Bu konuda ayrıntılı bir inceleme için bkz. (Derderian, 2014).

19 Bu konuda daha fazla bilgi için bkz. (Cankara, 2015).

20 Millet ve dil arasındaki birebir mütekabiliyet ilişkisi Jean-Jacques Rousseau ve Johann Gottfried von Herder'e kadar geriye götürülebilir. Bkz. (Rousseau 1998, s. 289) ve (Berlin 1976, s. 181-183).

21 Bu dergiyi, aşağıda değineceğim İzmirli ile birlikte bana sağlayan meslektaşım Ohannes Kılıçdağı'na teşekkür ederim. 
lerin umumı dimeyelim, ekserisi maeteesüf nizami bir tedrisden mahrum olub, pek sathi bir suretde tahsil-i ilmde bulunmışlar ve bu gün etraflarına bakıb hayat keşmakeşinde bulundıkları muhitde kendilerinin cehaletini hiss iderek pek derin bir peşimaniyete düçar olıyorlar. İşte bunların nedametlerini bir dereceye kadar ilğa itmek ve kendilerinde, bulındıkları muhite lazım olan hasais-i fikriyeyi ikmal itmek vazife-i mukaddesesi, ancak “Hüsn-1 Niyet” gibi bir resaleye münasib dir. "Hüsn-1 Niyet" seyyar bir mekteb yakhod bilcümle ülum u finunın muhtasar ve müfid bir mecmuası olmalı dır. Şu vazife çok müşkil ise de bir az sebat ve maddi metanet biraz olmadığı takdirde pek kolay olabilir (Terziyan 1911, s.13-14).

Alıntıda dikkat çekici olan, Ermeniceyi hiç bilmeyen Ermenilerin büyük çoğunluğunun düzenli bir eğitimden yoksun olduğunun vurgulanmasıdır. Dolayısıyla 19. yüzyıl boyunca Ermenicenin Osmanlı'nın bilhassa Ermeni cemaatinde sayıları hızla artan ve gelişen modern eğitim kurumları vasıtasıyla yaygınlaşmasına rağmen, sadece Türkçe bilen Ermenileri aydınlatma ihtiyacı hâlâ Ermeni harfli Türkçe yayın yapmak için geçerli bir neden olarak görülmektedir. Burada şunu da hesaba katmak gerekir: 1. Meşrutiyet'ten itibaren devlet memuru olabilmek için belli bir düzeyde Türkçe bilgisinin gerekmesi (Tanör 1998, s.146) ve Osmanlıcılık politikaları doğrultusunda açılan Mekteb-i Sultanî gibi karma yüksek okulların yine yüzyılın son çeyreğinde etkinlik kazanmaya başlaması (Somel 2010, s.68, 297), Ermenilerin en azından bir kısmı için Ermeniceye paralel olarak Türkçenin toplumsal işlevini değiştirmiş olmalıdır. Kısacası, dil açısından bakıldığında ortada sanıldığından daha karmaşık bir durum olduğu söylenebilir. Diğer bir deyişle, Ermenicenin ve millî bilincinin gelişip yaygınlaşmasına paralel olarak Ermeni harfli Türkçenin ortadan yavaş yavaş kalktığını söylemek, tamamen yanlış olmasa bile işin kolayına kaçmak olacaktır. Aşağıdaki alıntı bu bakımdan ilginçtir. 1909-1910 yıllarında İzmir'de yayımlanan "haftalık popüler edebiyat, ilim, siyaset, ticaret, mantık ve iktisat" gazetesi Izmirli'nin ${ }^{22}$ ikinci sayısında gazetenin yarısının niçin Türkçe basıldığı şu satırlarla açıklanıyordu:

"İzmirli" gazetamızın nısfını, ve rağbet gördükce ilerude belki de kısm-ı azamını türkce lisan ile neşr itmekdeki maksadımız evvela, Ermenice gazetalardan layıkıyıla istifade itmek derecesinde bulunmayan hemşehri mezhebdaşlarımıza ferdden yani hususdan umuma gitmek suretiyle hıdmet itmek, saniyen, cemiyet ve hükümet-i osmaniyeyi teşkil iden anasır-1 muhtelife meyanında mezhebdaşlarımın digerlere nisbetle türk unsurıyla daha ziyade temasda bulındıklarından ve bu kerre idare-i meşrutiyet muhasenatından olmak üzre bir türk konşısının elindeki türkce gazetada gördügi bir münazereyi, mübareseyi kendisine okudığında

22 Dergi hakkında daha fazla bilgi için bkz. (Stepanyan 2005, s. 594). 
ya anden bahs itdiginde 'öyle amma bak bizim gazeta da ne yolda yazıyor' deyerek ol münazerede kendusini müdafaasız ve ya bihaber bırakmamak, salisen' hususıyla İzmirde elsine-yi muhtelifede neşr olunan gazetaları birer birer okumağa luzumı kalmaksızın kendilerine alaka ve münasibeti olan tekmil haftalık havadisleri icmalen bildirmek dir. (Yeseyan 1909, s.15)

Bir önceki örnekte olduğu gibi, gazetenin Ermenice gazeteleri okuyamayanların yararlanması için Türkçe yayınlandığı burada da vurgulanmaktadır. Ancak ondan farklı olarak, şu anda yarısı Ermenice olan İzmirli'nin ileride belki de daha büyük bir bölümünün Türkçe basılabileceği belirtilmektedir. Aslında 8 sayfalık bu gazetenin ilk sayısının yalnızca son sayfası Ermeni harfli Türkçedir. İkinci sayıda ise hem yukarıda alıntıladığım açıklama yapılmış hem de bu kez son iki sayfa Türkçe olmuştur. Üstelik gazetenin bir bölümünün Türkçe olması gazetenin yayımcılarının mezhepleriyle ilişkilendirilmiştir ki bu akla önce Katolik Ermenileri getirmektedir. ${ }^{23}$ İlk sayının kapağında yer alan ve gazetenin amacını belirten yazıda ise gazetenin herkes tarafından ulaşılabilir (hanramançeli) olmasının hedeflendiği belirtilmiştir ("Mer Uğğutyunı" 1909, s.1). Bu durumda Ermeni harfli Türkçe kullanımının bütün Ermeni cemaatine ulaşma hedefinin bir parçası olduğu açıktır.

Son olarak, Ermeni harfli Türkçe yayımcılığı meşrulaştırmak için kullanılan önemli bir gerekçeden söz etmek gerekir. Her ne kadar aşağıdaki alıntı bir süreli yayından değil de bir kitabın önsözünden alınmış da olsa, Ermeni harfli Türkçe basına dair göz ardı edilmemesi gereken bir noktayı vurgulaması bakımından dikkate değerdir. Ermeni basını açısından önemli bir isim olan Hovsep Vartanyan ${ }^{24}$ Tarih-i Napolyon Bonaparte: Imperator-u Ahali-i Fransa

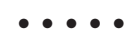

23 Ermeni Dilbilimci Hraçya Acaryan'a göre Ermeni Harfli Türkçeyi ihya edenler "ayrılıkçı bağnazlık"larıyla Katolik Ermenilerdi. Acaryan'a göre onlar Ermeni adından iğrenir ve Ermeni olarak anılmamak için yalnızca Türkçe konuşurlardı (Acaryan 1951, s.264). Şüphesiz, tartışmalı bir iddia bu. Nitekim Protestan misyonerlerin ve Ermenilerin ve mezhepler arası mücadelede geride kalmak istemeyen Ermeni Kilisesi'nin de yere ve zamana göre değişmekle birlikte, Ermeni harfli Türkçeyi yaygın bir biçimde kullandıkları görülmektedir.

24 "Osmanlı devlet adamı, gazeteci, müellif ve mütercim" Vartanyan Viyana'daki Mehitarist Manastırı'nda eğitim görmüş, 1837'de Bahriye tercümanı olmuş, 1856'da Encümen-i Dâniş harici azalığına seçilmiş ve ardından "paşa" ünvanı almıştır. 1860'tan itibaren mülki görevlerde bulunarak "bey" ünvanı alan Vartanyan, bilinen ilk (Ermeni harfli) Türkçe roman olan Akabi Hikâyesi' nin (1851) de yazarıdır. 1852' de Ermeni harfli Türkçe Mecmua-yı Havadis dergisini (daha sonra gazete olacak) çıarmaya başlamış, ölümüne kadar yine Ermeni harfli Türkçe yayımlanan Tercüman-ı Efkâr'ın başyazarlığını yapmış, Garabed Panosyan'ın Manzume-i Efkâr' 1 için yazılar yazmış ve Andon Alik'le birlikte Mamul gazetesini yayımlamıştır (Pamukciyan 2003, s.373). 
(1816-1879) başlıklı devasa kitabının önsözünde kitabını (Ermeni harflerini kullanarak) Türkçe yazmış olmasını şu sözlerle gerekçelendirir:

Hitam-1 kelamımızda bir başka ihtiraz da hatıra gelir; her ne süretde ise de, böyle bir tevarih te'lifine lisan-ı maderzadımız olan ibare-i Ermenian müraccah deyilmiyidi deyenler de bulunacak dır. Bunlara acizane cevabımız, Ermeni ve Türki, her hang1 lisande olur ise olsun, böyle bir tarihin mütalaası ile kesb-1 istifade itmek, bu iki lisandan birinin layıkı ile tahsiline mühtac bir keyfiet dir. Hatda Milletimizde Ermeni krapar lisanına aşna olanların adedi ğayet mahdud olub aşharhapar lisanı dahi henüz bir kanun ve kayide-yi umumiye tahtında olmadığından bu lisande kitab te'lif itmek her satırda krapardan luğetce müracaat itmeye mühtac olduğundan böyle aşharhapar lisanında yazılan te'lifatı da ağnamak yine krapar lisanı tahsil-i tekellüfüne mühtac olaca[ktır] (1855, s.3-4).

Bu alıntıdaki krapar, yani Klasik Ermenice, az sayıda Ermeni'nin bildiği ve kilise ayinleriyle kitaplar dışında toplumsal yaygınlığı olmayan bir yazı dili olup 19. yüzyılda yerini tedricen Modern Ermeniceye, yani aşkharhapar'a bırakmıştır. Vartanyan'ın bu satırları Ermeni harfli Türkçe yayıncılıkla ilgili bir durumu açıkça göstermektedir: Basın, doğası gereği, kitlelerin konuştuğu dili kullanmak ister ve dilin modernleşmesini, daha çok gündelik konuşma diline dayanan bir düzyazı dili haline gelmesini sağlar. Oysa Ermeni cemaati söz konusu olduğunda halihazırda "millî olmayan" bir dilin, Türkçenin yaygınlığı Ermeni harfli Türkçe metinlerin cemaat içinde bir tür lingua franca işlevi görmesini (zira çat pat da olsa Türkçe konuşan ve kiliseye gittiği için Ermeni harflerini tanuyan eğitimsiz bir Ermeni de okuyabilir bu metinleri, Bahriye baş tercümanlığı yapan ve Avrupa'da iyi eğitim alıp en az birkaç dili çok iyi bilen bir Ermeni de) sağlamış olmalıdır. ${ }^{25}$ Dolayısıyla, basın bir yandan Ermenicenin modernleşmesine katkıda bulunurken, bir yandan da Türkçe kullanmak durumunda kaldığında bu çelişkiyi açıklamak zorunluluğu hissetmiştir.

Yukarıda bazılarına değinilen kaynaklar göstermektedir ki Ermeni harfli Türkçe yazmayı ya da yayın yapmayı tercih edenler, neredeyse ilk örneklerinden itibaren seçimlerini açıklama ve meşrulaştırma ihtiyacı duymuşlardır. Burada öne sürülen en önemli gerekçeler Ermenilerin çoğunun ana dilinin Ermenice olmaması ya da Ermeniceyi bu dilde yazılmış metinleri okuyacak kadar iyi bilmemeleridir. Buna ek olarak, Modern Ermenicenin yeterince standartlaşmamış olduğunu; Ermenice bilmeyen yahut yalnızca konuşarak anlaşacak kadar bilen Ermenilerin düzenli bir eğitimden yoksun ve bu nedenle

25 Bu konuda daha ayrıntılı bir değerlendirme için bkz. (Cankara, 2015). 
aydınlatılmaya muhtaç olduklarını öne sürerek de Ermeni harfleriyle Türkçe yayın yapmanın meşrulaştırıldığı görülmektedir. Burada dikkate çeken noktalardan biri, 19. yüzyıl ortasında bir gazetenin Ermeni harfli Türkçeyi, diğer bir deyişle gündelik konuşma dilini (vernacular) tercih ederek, daha kozmopolit bir kitleye (içinde daha büyük bir Ermeni nüfusunu, ve bazı durumlarda Türkleri, Rumları vb. de barındıran bir kitle) ulaşıyor olmasıdır. ${ }^{26} \mathrm{Bu}$ tutum beraberinde bir "çifte aşağı" olma durumunu getirdiği gibi (zira tercih edilen hem gayr-1 millî hem de "kaba" bir dildir), Türkçe bilmeyen Ermenileri kapsayan (örneğin Rusya'dakiler) başka bir kozmopolit kitlenin de muhtemelen dişlanmasına neden olmaktadır.

\section{Ermeni harfli Türkçe basında kimlik meselesi: Ermenilik, Osmanlılık, vatan}

"Beni bu vatana düşman göstermek istediler, ben bu vatanın en sadık evladıyım." Bu sözler 1896 yılında görevinden istifa ederek Abdülhamit tarafından Kudüs'e sürülen Türkiye Ermenileri'nin 75. patriği Matteos İzmirliyan (18451910)'a aittir. ${ }^{27} \mathrm{Bu}$ satırlar yukarıda adı geçen Hüsn-i Niyet dergisinde yer alan ve “A. M." imzası taşıyan "Ben Bu Vatanın Sadık Evladıyım (1896-1908)" başlıklı yazıdandır. Yazıda İzmirliyan'ın patriklikten istifa etmeye zorlandığı 1896 yılına ait bir hatıra aktarılırken, onun şu sözlerine yer verilir:

Endişeye sebeb yok dır, şakhslar gelir gider, fakat millet bakıdır. Tarikh benim gibi çokların gitdigini gösteriyor. Ben yalınız milletime deyil, devlete de khıdmet etmek istedim; bu vatanın selametine başlıca medar olacak olan islahatın icrasını taleb itdim. Beni bu vatana düşman göstermek istediler, ben bu vatanın en sadık evladıyım. Abdül Hamid hükümeti ne bunı yapmağa meyyal dır ne deyapabilir, zira bu gün Anadoluda Kürdlere, ağalara öyle bir teesir vermiş dir ki, onı geri almak mümkin deyil dir. Bunın içün Evropa devletlerine müracaat itdim ki vadlarını icra itsinler. Bu yeni bir müdahele davet itmek deyil idi, zaten mevcud olan ve hükümetı Osmaniyece imzalanmış olan Berlin ahdnamesinin bir maddesinin icrası idi; beni süküt etdirmek içün asi göstermek, Türklere düşman, padişaha karşı khayın oldığımı ileri sürmek lazım idi, bunlar oldu. Ben Babı Ali vakaasından sonra işden el çekmek ister idim, fakat meclisler ve bazı şayanı itimad zevat beni koy vermediler; bu gün onlar da istifama muvafakat idiyorlar; ben tarikhden korkarım, beni kim getirdi ise istifamı o kabul itmeli, mümkin olsa idi Millet meclisini toplar istifamı ona verir idim. (M. 1911, s.3-4)

26 Cosmopolitan ve vernacular kavram çiftini Sheldon Pollock'tan ödünç alıyorum (Pollock, 2000).

27 İzmirliyan hakkında daha fazla bilgi için bkz. (Pamukciyan 2003, s.254-255). 
Burada İzmirliyan’ın sözlerinin doğruluğu tartışılmayacaktır. Önemli olan Hüsn'i Niyet'in üzerinden on beş yıl geçmiş olmasına rağmen, üstelik ilk ve son sayısında, derginin sunuş yazısından hemen sonra bu olay üzerine bir yazıya yer vermesidir. Buradaki Osmanlılık vurgusu açıtır. Yazar bu sözleri aktararak, İzmirliyan'ın hem milletine hem devletine sadik olduğunun, yani hem Ermeni hem Osmanlı kimliğinin altını çizmektedir. Dergideki bir sonraki yazıda da (Onnig Bakırcıyan imzasını taşıyan "Siasi İktisadi Programın Elzemiyeti” başlıklı yazı) aynı vurgu bulunmaktadır. Başlığından da anlaşılacağı üzere, Bakırcıyan "Mesuliyetsiz Meşrutiyet ve Meşrutiyetsiz Mesuliyet olamaz" sloganını vurguladığı yazısında, Ermeni milletinin değil "Memalik-i Osmaniye' nin", yani "memalikimizin terakkisi" için gerekli "dahili ve harici" ekonomik tedbirlere dair görüşlerini dile getirmiştir: "Siasi ve iktisadi program!... işte terakkı-yı memleketin miftahı, tekemmül-i milletin rehberi ve saadet u refahı Osmanyanın merci-i yegânesi..." (1911, s.5). Bakırcıyan'ın bu yazısını K. Dandanyan'ın "Memleketimizde Ticaret ve Sanayi Neden Terakkı İtmeyor?" başlıklı yazısı takip eder. Dandanyan da özelde Hüsn-i Niyet'te genelde burada değindiğimiz diğer süreli yayınlarda olduğu gibi, hukukun ve kanunlarının gerekliliğinin altını çizerek başlar yazısına:

Evvela bir memleketde saadet-i umumiyenin ve rifah-1 ammenin husuli ahval-i iktisadiyesindeki mükemmeliyete vabeste dir, bir memleketde kanunlar ne kadar adılane, muamelat ne kadar hakimane icra idilirse, o kadar terakkı ve tekâmüle doğru khatveler atılmış olır; kanunlar adilane icra olunmazsa o memleketde ehali sanayi ve zraatdan mahrum olır; ve dayma orada muhib bir fakr u sefalet yekünü nazar-1 teesüfe çarpmakdan khali kalmaz. İkinci, memleketin ticaret ve sanayi nokta-yi nazarından biriside, o memleketin erbab-1 serveti yekvucud ittihad ve imtizac itmeleriyle kayim ola bilir; işte bu iki şıkkın behemehal vücudı bir memleket içün elzem dir (Dandanyan 1911, s.10).

Burada Dandanyan bir ülkenin refahını ekonomik koşulların iyileştirilmesine ve bunu da hukukun üstünlüğüne bağlamakla kalmamakta, sermayenin de iş birliğinin gerekli olduğunu öne sürmektedir.

Özetle, 1911 yılında sadece bir sayı çıkmayı başarabilmiş -ki bunun nedeni de ayrı bir inceleme konusudur- 16 sayfalık Hüsn-i Niyet'in oldukça güçlü bir Osmanlılık vurgusu yaptığını söylemek yanlış olmaz.

Peki bu alıntılar ne ölçüde bir toplumsal tutumu yansıtırlar? Bu konuda elimizdeki en güncel ve önemli çalışma Ohannes Kılıçdağı'nın henüz yayımlanmamış olan Socio-Political Reflections and Expectations of the Ottoman Armenians after the 1908 Revolution: Between Hope and Despair başlıklı doktora 
tezidir. Kılıçdağı 1908 sonrası Osmanlı Ermenilerinin devletle ve diğer toplumsal gruplarla ilişkilerini nasıl algıladıklarını anlayabilmek için, başka kaynakların yanı sıra Sivas, Tokat, Erzurum, Trabzon, Harput, Adapazarı ve İzmir gibi Anadolu kentlerinde çıkan süreli yayınları da incelemiştir ki bu da Osmanlı Ermenilerinin çoğunluğu anlamına gelir. Tezin güçlü yanlarından biri Ermeni cemaati içindeki bölünmeleri (sınıfsal, dinsel vb.) dikkate alması, güç ilişklerini değerlendirirken yekpare bir cemaat varsaymamasıdır. Ancak yine de görünen o ki belli dönemeçlerde ortak yönelimlerden bahsetmek mümkün hale gelmektedir. Örneğin, 1908, cemaatin bütün grupları tarafından Abdülhamit rejiminin baskısından kurtuluş olarak algılanmıştır. 1909'da Hınçak Partisi'nin Sivas Şubesi'nin Osmanlı'nın meşrutî yönetimine karşı her türden ayrılıkçı hareketi reddetiğini, meşrutiyetin dahilî ve haricî düşmanlarına karşı özgürlükçü Türk kardeşleriyle omuz omuza mücadele edeceğini ve Osmanlı vatanının evlatlarının içine girecekleri dayanışmanın bu ülkeyi cennete çevireceğini deklare etmiş olması dikkat çekicidir. 1909'daki Adana katliamlarından sonra dahi meşrutî Osmanlı'dan kopmadan millî kimliği koruma fikrinin Anadolu'daki Ermeni basınında hakim olduğu görülebilmektedir (Kılıçdağı 2014, s.189-191). Burada iki noktanın altını çizmekte fayda var gibi görünüyor: Birincisi, dış tehditlere karşı Osmanlı Ermenilerinin ortak çıkarlar doğrultusunda Osmanlılık fikrini benimsemeleri. İkincisi, “Osmanlılık" ve "Ermenilik" in birbiriyle çelişen kategoriler olarak algılamamaları. Bu anlayışa göre, aynı anda eşit derecede Osmanlı ve Ermeni olmak mümkün, bunlardan birini diğer için feda etmek gereksizdi. Önemli olan bölünmez bir bütün olan Osmanlı vatanının bayrağı altında eşitçe ve özgürce yaşayıp ortak amaçlar için birlikte çalışabilmekti. Dolayısıyla burada Ermeniler için bir çifte sorumluluk durumu ortaya çıkıyordu; bir yandan devlete, diğer yandan da Ermeni cemaatine karşı (s.192, 198, 210-211).

İşte yukarıda İzmirliyan'dan yapılan alıntının anlamı da budur. Ermeni harfleriyle Türkçe yayımlanan Hüsn-i Niyet, ister İzmirliyan dosyasını yıllar sonra yeniden hatırlatarak ister Memalik-i Osmaniye'nin iktisadî kalkınması için ortak bir program önererek isterse eğitim olanaklarından yeterince nasiplenmemiş milletdaşlarını aydınlatabilmek amacıyla Ermeni harfleriyle Türkçe yayım yapmayı tercih ederek olsun, Ermeni kalarak Osmanlı olmanın bir yolunu temsil etmektedir. Bu şekilde Müslüman/Türk vatandaşlarıyla aralarında dilsel bir bă̆ bulunan Ermenilere siyasi birlik fikri de aşılamaya çalışmaktadır. Üstelik bu yayınları çıkaranlar, yayınlarının Müslüman/Türkler ve hatta başka gruplar tarafından takip edildiğinin de bilincindeydiler. Bu nedenle de Ermeni harfli Türkçe süreli yayınların çifte işlevlilik durumunu, sırf Ermenice yayımlananlara nazaran daha iyi temsil ettikleri ileri sürülebilir. 
Ermeni harfli Türkçe basından alınan bu örnekler, Orhan Koloğlu'nun bilhassa 2. Meşrutiyet Ermeni basınına dair yazının başında alıntılanan yargısının yanlışlığını açıkça göstermektedir. Bu durumu sadece 1908'in hemen akabindeki iyimser havaya bağlamak da yanlış olacaktır. O halde tarihi biraz daha ileriye ve geriye alıp tekrar bakalım.

Asia 1872-1873 yıllarında İstanbul'da Ermenice ve Ermeni harfleriyle Türkçe yayımlanan "Milli, edebi, siyasi ve başka konuları içeren [bir] dergi" dir. ${ }^{28}$ Bu tarih aynı zamanda ilk Ermeni devrimci örgütün Van'da kurulduğu tarihtir (Kılıçdağ 1 2014, s.86). Alt başlığ1 “Tercüman-1 Vatan” (tarkman hayrenyats) olan derginin ilk sayısı "Ben-i Adem Aza-yi Yek Digerend" başlıklı imzasız bir yazıyla ve şu satırlarla açılmaktadır: "Yani efrad-ı ben-i adem bir vicud-1 manevinin (ki insaniyet dir) azası olduğu itikadındayız, ve hakk-1 tabii (ki beşeriyet hılkatinde bu fazilet ile tekrim buyurmuş dır) kitabımız dır, ve adalet $\mathrm{u}$ insaf elde mizanımız dır" ("Ben-i Adem Aza-yi Yek Digerend" 1872, s.1). Adalet, insaf, insanlık ve hukukun herkes için gerekliliğinin vurguland1ğı yazıda derginin çıkış amaçları şöyle sıralanmaktadır:

Asia vazifesini şu dört şeylerden ibaret bilir: evvela tasfiye-i akhlâk, ve istihsal-1 maarif ve senaiye vatan kardaşlarını teşvik itmek; sania mani-i tereki olan efkâr-1 batıleyi halkımızdan gidermeğe çalışmak; salisa vatanın menafiin, hukukun müşterek olduğunu anlatmak, ve geçmişleri unutdurmakla ve el birliği ile çalışmanın fayidelerini göstermekle vetan karndaşlarına gelecegi şahid maksud itdirmek; rabia yapılmasını khayırlı ve menfaatlı bildigi şeyleri ikhtar etmek (s.1).

Buradaki adalet vurgusunun samimiyetini sorgulamak isteyenler için Asia'nın İbret gazetesinin kapatılma davasını takip edip bununla ilgili haberlere yer verdiğini de belirtmek gerekir. Söz konusu kapatılma, Namık Kemal'in gazetenin 9 Temmuz 1872 tarihli 19. sayısında yer alan "Garez Marazdır" yazısı üzerine gerçekleşmiştir (Özön 1997 [1938], s.44, 110-112). Bu örnek, Ermeni harfli Türkçe ve Arap harfli Türkçe gazeteler arasındaki geçişililik açısından önemlidir. ${ }^{29}$ Derginin ikinci sayısı da "Vatan" başlıklı ve yine imzasız bir yazıyla açılır:

İnsanın vatan-ı hakıkesi, üzerinde sakin olduğu kürredir. Ve bu kürrede temellük ve taayyüş itmek haklarında her insan müsavidir. Çünki, kürre-yi arz ne bir, ne de birkaç fırka için yaradılmayub, bilcümle efrad-ı ben-i adem içün yaradılmışdır.

28 Bu konuda daha fazla bilgi için bkz. (Stepanyan 2005, s.573).

29 Müslüman/Türk gazeteciler de çeşitli nedenlerle Ermeni harfli Türkçe yayınları takip ediyorlard1 (Cankara, 2015). 
Her ne cinsden, her ne her ne dinden, olur ise olsun, her insanın kürre-yi arzın her kıtasında tevattun ve temellük ve teayüş cihetlerinde müsavat üzre hakkı vardır. Şu kadar ki, efrad-ı ben-i adem birçok sebeplerden dolayı cemaatlere taksim olunmuş, ve her cemaat kürrenin bir cihetinde temekkün ile o mahali kendisine makhsus lisan, din, adet, kanun, ittikhaz ve ikhtiyar itmiş olduğundan, itibari vatanlar teaddüd itmiş dir. Gerek hakiyki olsun gerek itibari olsun vatanını sevmek menafi ve iymarına çalışmak her insanın vazifesidir (??? 1872, s.9).

Şüphesiz Asia'nın ve yukarıda adı geçen diğer süreli yayınların daha sağlıklı değerlendirilebilmesi için ayrıntılı monografilere ihtiyaç bulunmaktadır. Öte yandan, ister 2. Meşrutiyet öncesinde olsun ister sonrasında ister bu niyetle olsun ister şu niyetle, bir arada yaşama iradesini ortaya koyan ve Osmanlılık üst kimliğinin, ortak hukukun ve ortak menfaatler için çalışmanın gerekliliğini vurgulayan, üstelik bir yandan da Ermeni cemaatinin sorunlarıyla ilgilenen, Ermeni kimliğini benimseyen ve bunda bir çelişki görmeyen süreli yayınlar, sayısı ne olursa olsun, mevcuttur. Bu süreli yayınlar incelendiğinde genelllikle Ermeni cemaatine ilişkin haber ve yazıların "Millı̀" (azkayin) başlığı altında (diğerleri "dahiliye", "hariciye" ve "mütenevviye" bölümlerinde yer alır) toplandığı görülür, ki bu da Osmanlı üst kimliğiyle Ermeniliğe dair algıyı ve bilhassa Ermeni harfli Türkçe süreli yayınların yerine getirdiği çifte işlevi göstermesi bakımından önemlidir.

Son olarak, daha kritik bir tarihe, 1915 yılına giderek Ermeni harfli Türkçe basındaki çifte kimliklilik vurgusunun bir sürekliliği olduğunu, yalnızca 19. yüzyıl sonuyla ya da 2. Meşrutiyet'in sağladığı iyimser havayla sınırlı bulunmadığını göstermiş olalım.

Hasmik Stepanyan'ın bibliyografyası'na bakılırsa Rahnüma [önder] Protestan misyoner Ermeniler tarafından (Bible House) 1911-1914 yılları arasında İstanbul'da, 1924-1934 yılları arasında da New York'ta çıkarılan "haftalık din, ahlak, ilim ve siyaset gazetesi" dir (2005, s.597). Halbuki Rahnüma 1915 yılında da- en azından bu makalenin yazarının ulaşabildiği kadarıyla- 25 Haziran'da çıkan 26. sayıya kadar yayımlanmıştır. "Misyoner yayını" terimi beraberinde doğal olarak bir beklenti de yaratmaktadır; İncil'den pasajlarla ve tasvirlerle süslenmiş, her satırında okurunu Protestanlığa davet eden bir gazeteyle karşılaşacağını düşünebilir insan. Oysa 1915 yılının ortalarına kadar çıkmayı başarmış -ki eğer gerçekten böyleyse bunda 24 Nisan tutuklamalarının ve tehcir kararının rolü olduğu düşünülebilir-Rahnüma' nın sayfaları karıştırıldığında durumun pek de öyle olmadığı görülmektedir. Derginin Birinci Dünya Savaşı'nın tüm hararetiyle kendini hissettirdiği 1 Ocak 1915'te çıkan sayısının giriş yazısında şu soru sorulur: “Söyleyiniz cihan tarikhi[nde] böyle bir sene 
başlamış mıdır, ve kim bilir, bir daha başlayacak mıdır?" Yazara göre 1915 Avrupa için benzersiz felaketlere gebedir: "Dünya khalk olunalı mürur eden seneler arasında 1915 yekta bir sene olacak dır. Evropa karasında yaşayan 445 milion insanlardan 115 milionı bir tarafda, 233 milionı diger tarafta olduğu halde biri birleri ile harb etmekdedirler. Geride kalan 100 milionın üç rubı öyle bir vaziyetde dirler ki anlerin 1915'i bitaraflıkla geçireceklerine inanmak içün insan aklını kaçırmış olmalı" (Nakkaşyan 1915, s.1). Burada önemli olan Nakkaşyan'ın öngörülerinin geçerliliği değil, bir misyoner yayını olan Rahnüma'nın siyasetle ilişkilenme biçimidir. Gerçi şu itiraz öne sürülebilir: Bir süreli yayın ister misyonerler tarafından çıkarılsın isterse sadece edebiyat üzerine olsun, bu ölçekte bir savaşı görmezden gelebilir mi? Ancak Rahnüma bu kadarıyla kalmaz. Savaşta siper kazma yöntemleri, zeplinlerin savaşın kaderini belirleyip belirleyemeyeceği, cephelerdeki son durumlar (asker sevkiyatına dair bilgiler de dahil olmak üzere), Almanların savaşa bakış açısı vb. üzerine yazılar da yer alır dergide. Dahası, Çanakkale cephesinden ayrıntılı haberleri de okumak mümkündür derginin sayfalarında. Bunların yanı sıra mebus seçimleri, meclis-i mebusandaki bütçe tartışmaları, Halep çıbanının tanı ve tedavisi, modern Ermeni edebiyatı hakkında haber ve yazılar da bulunmaktadır Rahnüma'da. Öyle ki Protestan cemaatiyle ilgili haberlerin ya da dinsel metinlerin dergide diğerlerine oranla daha az yer kapladığı görülür. Haber ve yazılardaki dil, buraya kadar alıntılarla desteklenmeye çalışılan Osmanlılık vurgusu bakımından kayda değerdir:

Bir de şu münasibetle geçen sene başında tebrik eylediyimiz bir çok sevgülüleri der khatır edelim, anler bu sene nerede dirler? Bu sabah yeni senelerini tekrar tebrik eylemek içün anleri meydan-ı harbin hangi köşesinde arayacağız? Erzrumın kar ile kaplı yaylalarında mı, Balkanın furtunalı ve barid dağlarında mı, yoksa Basra ve Akabanın [sic] beyaban çöllerinde mi? Zevcelerin sevgülü gencleri, şefik validenin canpare evladı, birinin sevgülü biraderi, ol birinin kıymetli pederi, ol şirin familya acağından ayrılıb, kendi kendilerini vatan ve hakıkat uğuruna ateşlere saldırmışlar dır (Cebecyan 1915, s.7).

Dergideki diğer yazılarda da "cephede vatan için savaşan evlatlar"dan, "vatanperverlik"ten, Gelibolu'dan, “düşman"lardan ve Pazar okullarında cepheye gidecek askerleri bilinçlendirmenin gerekliliğinden bahsedilmektedir.

Son olarak, derginin sayfalarında "Din̂̂" başlı̆̆ı altında Türk milliyetçiliğinin şiirdeki öncülerinden Mehmet Emin Yurdakul'un ${ }^{30}$ (1869-1944) "Günâhkar" başlıklı şiirinin yer aldığını da belirtmek gerekiyor:

30 Şiirin altında şairin ismi "Muhammed Emin" olarak verilmiştir. 
Ben bir zından içindeki mahbuslara benzerim, / Benim dahi ayağımda ağır, paslı demirler / Benim dahi vücudumı mermer taşlar zehrler, / Benim dahi karanlıkda 1şık arar gözlerim. / Nerde bulsam... Nerdesin sen, Ey mübarek teselli? / Artık yeter! Bu hayalı yok et benim önümden, / Artık yeter! Bu azabı çıkar benim gönlümden. / Ah! Kaldırın üzerimden beni döyen şu eli... / Ey masumlar! Şu gök, şu yer, hep kâinat sizin dir, / Gülme, sevme, alkış, türkü, ümid, hayat sizin dir, / Yalınız bir dar mezar gerek bir günahkâr insana. / -Hayır, yaşa! Ve kendini yeni doğmuş biri bil, / Her gün küçük bir hayır yap, yanaklardan yaşlar sil, / Ta ki senin ruhun dahi bir teselli kazana ( 1915, s.105).

\section{Sonuç}

Bir kez daha yinelemek pahasına belirtmek gerekir ki burada Ermeni harfli Türkçe basınla ilgili kapsamlı bir araştırmanın sonuçları dile getirilmemiştir. Osmanlı/Türk (basını) tarihyazımındaki bazı yöntemsel sorunların altı çizilip, ulaşabilen sınırlı sayıda kaynaktan yola çıkarak hikâyenin tam da anlatıldığı gibi olmadığı vurgulanmaktadır. Şu ana kadar değinilen kaynaklar göstermektedir ki Ermeni basını yekpare bir bütünden oluşmamakta ve kendi içinde müthiş bir çeşitliliği barındırmaktadır. Bu basının tümüyle ayrılıkçı eylemlerle bağdaştırılması bir çarpıtmadan ya da seçici okumadan öteye gitmez. Burada da bu anlayışa karşı ve yine seçici bir okuma yapılmıştır, ancak bu konuya dair bir sinırlamadan kaynaklanmaktadır. Umulur ki Ermeni harfli Türkçe yayın koleksiyonları oluşturulsun, kullanıma açılsın ve araştırmacılar tarafından didik didik edilerek mevcut tarihyazımı daha güçlü bir biçimde gözden geçirilsin. Bu makalede değinilen Ermeni harfli Türkçe yayınlara bakıldığında, 1908 öncesinde de sonrasında da bir arada yaşamayı ve ortak bir hukukun gerekliliğini savunan Osmanlıcı bir tutumun varlığı görülebilmektedir. Üstelik bu tutuma Protestan misyonerler tarafından yayımlanan haftalık bir süreli yayının 1915'teki sayılarında da rastlanmaktadır. Bu yayınlarda çoğul kimliklerin, aynı anda hem Ermeni hem Osmanlı olunabileceğinin ve önemli olanın ortak bir vatanın menfaatleri için -kendi kimliğinden vaz geçmeden- iş birliği yapmak olduğunun altı çizilmektedir. Yukarıda adı geçen Hovsep Vartanyan çoğul kimlikler konusunda ilk akla gelen isimlerden biridir; hem Katolik Ermeni cemaatine hem Ermeni milletine hem de Osmanlı devletine hizmet ediyordu Vartanyan. Üstelik Katolik kimliğinin içinde bir de Mehitarist kimliği vardı. Yine yukarıdaki örnekler göstermektedir ki pek çok durumda Müslüman/Türk basınla ortak bir dil kullanılmıştır, bu süreli yayınlarda. Aralarında geçişlilikler olduğunu, birbirlerinden sanıldığı kadar kopuk olmadıklarını gözlemlemek de mümkündür. Burada özellikle Ermeni harfli Türkçe basının önemli bir rol oynamış olabileceğini vurgulamak gere- 
kir: Bir yandan düşük prestijli ve millî uyanış açısından kabul edilemez olan "kaba Türkçe" yi kullanarak daha geniş bir okur kitlesine ulaşmayı ve onları bilinçlendirmeyi hedefleyen, bir yandan da büyük olasılıkla kendi cemaatleriyle diğer cemaat ve milletler arasında köprü oluşturan bu "iki kere aşağı" yayınlar, cemaat içinde ve dişında ikili bir işleve sahiptiler. Bunlardan bir bölümünün Türkçenin düzyazı dili haline gelişine katkıda bulunmuş olması da gayet makul ve incelenmesi gereken bir olasılıktır. Şimdi artık bu dergi ve gazeteler üzerine monografiler yazmak, onları Latin harflerine aktarmak, onları dönemlerinin Arap harfli süreli yayınlarıyla karşılaştırmak ve aralarındaki geçişliliklerin, etkileşimlerin peşine düşmek gerekiyor. 


\section{Kaynakça}

ACARYAN, H. (1902) Turkereni aztetsutyun hayereni vra yev turkerene pokharyal parer bolsi hay joğovrtagan lezvin meç hamamadutyamp vani, karabaği yev nor-nahçevani parparnerun. Moskova.

ACARYAN, H. (1951) Hayots Lezvi Badmutyun (C. 2). Yerevan: Haybedhrad.

ALTOUNIAN, V. ve ALTOUNIAN, J. (2014) Geri dönüşü yok: bir babanın güncesinde ve kızının belleğinde Ermeni soykırımı. Çev. R. Akman. İstanbul: Aras Yayıncılık.

BAKAR, B. (2009) Ermeni tehciri. Ankara: Atatürk Araştırma Merkezi.

BAKIRCIYAN, O. (1911) Siasi iktisadi programın elzemiyeti. Hüsn-i Niyet, 1, s.5-7.

BARDAKJIAN, K. B. (2013) Modern Ermeni edebiyatı. Çev. F. Ünal ve M. Aktokmakyan. İstanbul: Aras Yayıncılık.

Ben-i Adem Aza-yi Yek Digerend (1872) Asia, (1) , s.1-2.

BERLIN, I. (1976) Vico and Herder: two studies in the history of ideas. London: Chatto \& Windus.

CANKARA, M. (2011) Imparatorluk ve roman: Ermeni harfli Türkçe romanları Osmanll/ Türk edebiyat tarihyazımında konumlandırmak. Yayınlanmamış tez (Doktora), İhsan Doğramacı Bilkent Üniversitesi Ekonomi ve Sosyal Bilimler Enstitüsü.

CANKARA, M. (2014) Ermeni harfleriyle ilk Türkçe romanlar üzerine. ALTUĞ, F. ve USLU, M. F. (der.) içinde. Tanzimat ve edebiyat: Osmanli İstanbulu'nda modern edebi kültürr. İstanbul: İş Bankası Kültür Yayınları, s.115-137.

CANKARA, M. (2015) Rethinking Ottoman cross-cultural encounters: Turks and the Armenian alphabet. Middle Eastern Studies, 51(1), s.1-16.

CEBECYAN, A. H. (1915) Yeni sene mütalâları. Rahnüma, 1, s.6-8.

DANDANYAN, K. (1911) Memleketimizde ticaret ve sanayi neden terakkı itmeyor? Hüsn-i Niyet, (1), s.9-10.

DEMIR, K. (2014) Osmanlı' da basının doğuşu ve gazeteler. Iğdır Üniversitesi Sosyal Bilimler Dergisi, (5), s.57-88.

DERDERİAN, D. (2014) Mapping the fatherland: Artzvi Vaspurakan's reforms through the memory of the past. TACHJIAN, V. (der.) içinde. Ottoman Armenians: life, culture, society (C. 1). Berlin: Houshamadyan Publication, s.145-169.

HETZER, A. (1987) Dačkerēn-Texte: eine Chrestomathie aus Armenierdrucken des 19. Jahrhunderts in türkischer Sprache. Wiesbaden: O. Harrassowitz.

KABACALI, A. (2000) Başlangıcından günümüze Türkiye'de matbaa, basın ve yayın. İstanbul: Literatür Yayıncılık. 
KARDAŞ, A. (2013) Osmanlı Devleti'nin son döneminde Van'da basın (1908-1915). Turkish Studies, 8(13), s.1189-1204.

KILIÇDAĞI, O. (2014) Socio-political reflections and expectations of the Ottoman Armenians after the 1908 revolution: Between Hope and Despair. Yayınlanmamış tez (Doktora), Boğaziçi Üniversitesi Sosyal Bilimler Enstitüsü.

KOLOĞLU, O. (2010) Osmanlı dönemi basınının içeriğ̈i. İstanbul: İstanbul Üniversitesi İletişim Fakültesi Yayınları.

KOPTAŞ, R. (2002) Ermeni harfleriyle Türkçe. PAMUKCIYAN, K. (der.) içinde. Ermeni harfli Türkçe metinler. İstanbul: Aras Yayıncılık, s. XI-LVI.

KOZ, M. S. (der.) (2014) Gül ağacı boy vermez: Ermeni harfli Türkçe ve Ermenice mâniler. İstanbul: Turkuaz Yayınları.

KRAELITZ-GREIFENHORST, F. von. (1996) Ermeni harfleriyle Türkçe hakkında çalışmalar. Kebikeç, (4), s.13-33.

KUT, T. (1985) Ermeni harfli Türkçe telif ve tercüme romanlar (C. 1). Beşinci Milletlerarası Türkoloji Kongresi, İstanbul Üniversitesi Edebiyat Fakültesi.

M., A. (1911) “Ben Bu Vatanın Sadık Evladıyım” (1896-1908). Hüsn-i Niyet, (1), s.1-5.

Mer Uğğutyunı (1909) İzmirli, 1, s.1.

MILDANOĞLU, Z. (2014) Ermenice süreli yaymlar: 1794-2000. İstanbul: Aras Yayıncilik.

NAKKAŞYAN, A. S. (1915) 1915 senesi. Rahnüma, 1, s.1-3.

Namag (1858) Ardzvi Vasburagan, 10, s.266-271.

ORAL, H. (2010) Yeni alfabede Ermeni imzası. NTV Tarih, 21, s.34.

ÖZÖN, M. N. (1997) Namık Kemal ve İbret Gazetesi. İstanbul: Yapı Kredi Yayınları.

PAMUKCIYAN, K. (2002) Ermeni harfli Türkçe metinler. İstanbul: Aras Yayıncıllk.

PAMUKCIYYAN, K. (2003) Biyografileriyle Ermeniler. İstanbul: Aras Yayınc1lık.

PAPLOYAN, M. A. (1986) Hay barperagan mamulě: madenakidagan hamahavak' Ts'uts'ag (1794-1980). Erevan: Haygagan SAH KA Hradaragch'ut'yun.

POLLOCK, S. (2000) Cosmopolitan and vernacular in history. Public Culture, 12(3), s.591-625.

ROUSSEAU, J. (1998) Essay on the origin of languages and writings related to music. Çev. J. T. Scott. Hannover: University Press of New England.

SAIRIO, A. ve PALANDER-COLLIN, M. (2012) The Reconstruction of prestige patterns in language history. HERNÁNDEZ-CAMPOY, J. M. ve CONDESILVESTRE, J. C. (der.) içinde. The Handbook of historical sociolinguistics. Chichester, West Sussex:Wiley-Blackwell, s.626-638. 
SOMEL, S. A. (2010) Osmanlı'da eğitimin modernleşmesi, 1839-1908: İslâmlaşma, otokrasi ve disiplin. Çev. O. Yener. İstanbul: İletişim Yayınları.

SPIVAK, G. C. (2003) Can the subaltern speak? ASHCROFT, B. vd. (der.) içinde. The post-colonial studies reader. London and New York: Routledge, s.24-28.

STEPANYAN, H. (2005) Ermeni harfli Türkçe kitaplar ve süreli yayınlar bibliyografyası, 1727-1968. İstanbul: Turkuaz Yayınları.

TANÖR, B. (1998) Osmanll-Türk anayasal gelişmeleri, 1789-1980. İstanbul: Yap1 Kredi Yayınları.

Tanzimat'tan cumhuriyet'e Türkiye ansiklopedisi. (1985) İstanbul: İletişim Yayınları.

TEOTİG. (2012) Baskı ve harf: Ermeni matbaacılık tarihi. Çev. S. Malhasyan ve A. İncidüzen. İstanbul: Birzamanlar Yayıncılık.

TERZIYYAN, H. H. (1911) Niyet nedir ve "hüsn-i niyet" nasıl olmalıdır? Hüsn-i Niyet, 1, s.13-14.

TETIK, A. vd. (2008) Ermeni komitelerinin amaçları ve eylemleri (Meşrutiyet'in ilanından önce ve sonra). Ankara: Genelkurmay Askerî Tarih ve Stratejik Etüt Başkanlığı Yayınları.

TOPUZ, H. (1973) 100 soruda Türk basın tarihi. İstanbul: Gerçek Yayınevi.

TUĞLACI, P. (2004) Tarih boyunca Batı Ermenileri. İstanbul: Pars Yayın ve Tic. Ltd. Şti.

URAS, E. (1976) Tarihte Ermeniler ve Ermeni meselesi. İstanbul: Belge Yayınları.

Vatan (1872) Asia, 2, s.9-10.

WARDHAUGH, R. (2006) An introduction to sociolinguistics. Singapore: John Wiley \& Sons.

YARMAN, A. (2012) Ermeni yazılı kültürü: harf, elyazması, matbaa ve salnâmeler tarihine kısa bir bakış. İstanbul: Türkiye Ermenileri Patrikliği.

YESEYAN, O. (1909) Mütalâ. İzmirli, 2, s.15-16.

YURDAKUL, M. E. (1915) Günahkâr. Rahnüma, 7, s.105.

ZARBHANALIAN, K. (1905) Badmut'iwn Hayerēn Tbrut'yan (P. Nor Madenakrut'iwn). Venedig: I Dbarani Mkhit'aryants'. 